\title{
Endoparasites of Domesticated Animals That Originated in the Neo-Tropics (New World Tropics)
}

\author{
Kegan Romelle Jones ${ }^{1,2, *}$ and Gary Wayne Garcia ${ }^{2}$ \\ 1 The Department of Basic Veterinary Sciences (DBVS), School of Veterinary Medicine (SVM), \\ Faculty of Medical Sciences (FMS), The University of the West Indies (UWI), Mt. Hope, Trinidad and Tobago \\ 2 The Open Tropical Forage-Animal Production Laboratory (OTF-APL), \\ Department of Food Production (DFP), Faculty of Food and Agriculture (FFA), \\ The University of the West Indies (UWI), St. Augustine, Trinidad and Tobago; prof.gary.garcia@gmail.com \\ * Correspondence: keganjones11@gmail.com; Tel.: +1-868-787-0833
}

Received: 14 February 2019; Accepted: 28 February 2019; Published: 6 March 2019

check for updates

\begin{abstract}
This review serves to summarize parasites found in Domesticated animals which were found in the Neo-Tropics. Indigenous domesticated Neo-tropical animals include South American camelids, (Lama gunacoa, Lama glama, Lama pacos, Vicuna vicuna), guinea pigs (Cavia porcellus), chinchillas (Chinchilla lanigera), turkeys (Meleagris gallopavo) and ducks (Cairina moschata, Anas platyrhynchos, Dendrocyga autumnalis). These animals were chosen due to their origin of existence (Neo-tropics) and over time these animals became domesticated and were distributed throughout the world. Over eighty (80) references were collected for this review and the papers spanned over eighty (80) years from 1934 to 2018. The gastrointestinal parasites reported for each animal were tabulated and their effects in the animal noted. Parasites reported in domesticated Neo-tropical animals had little to no effect on wild and free ranging animals with a few cases of illness and decreased productivity. The majority of articles viewed these animals as reservoir host which can infect humans and other domesticated livestock. It must also be noted that research done in the past did not focus on the effect these parasites had on these animals but only observed their potential as reservoirs for parasitic diseases.
\end{abstract}

Keywords: Cavia porcellus; Meleagris gallopavo; Chinchilla lanigera; South American camelids; Carina moschata; Anas platyrhynchos; Dendrocyga autumnalis

\section{Introduction}

Livestock which are present in the Neo-tropics can be divided into three categories. The first group was domesticated animals introduced in to the Neo-tropics. These included cattle (Bos indicus, Bos taurus), sheep (Ovis aries), goat (Capri hircus), chickens (Gallus domesticus), horses (Equus caballus) and pigs (Sus sucrofa). The second group was domesticated animals which were found in the Neo-tropics. These included South American Camelids (SAC) (Lama gunacoa, Lama glama, Lama pacos Vicuna vicuna), guinea pigs (Cavia porcellus), chinchillas (Chinchilla lanigera), turkeys (Meleagris gallopavo) and ducks (Cairina moschata, Anas platyrhynchos). These animals have been used by humans for many purposes. South American camelids have been used for fur and meat, guinea pigs have been used for meat and laboratory research, chinchillas have been used in the production of fur coats, turkeys and ducks have been used for meat production [1]. The third groups of animals are Non-domesticated Neo-tropical animals. These included the agouti (Dasyprocta leporina), lappe (Agouti paca), manicou, (Didelphis marsupialis insularis) red brocket deer (Mazama americana), capybara (Hydrochaerus hydrochaeris) and collared peccary (Peccari tajucu) [2]. 
Little information is known on the effect of these parasites on the non-domesticated neo-tropical animals. In recent times some work has been done on the reproductive system of the agouti $[3,4]$, nutrition of the agouti [5-7], parasites in wild and captive reared agoutis [8-10], the blood profile of agoutis reared in captivity [11], biology of the manicou [12] and digestive anatomy of the red brocket deer [13].

Parasites which were found in the domesticated species introduced into the Neo-tropics have been well documented [14-16]. Recently, the gastrointestinal parasites present in these animals were reviewed. Parasites were summarized as organisms which negatively affected the animals' health and performance by removal of essential nutrients and its effect can be seen clinically or sub-clinically [17].

The objectives of this review were (1) to identify the gastrointestinal parasites of South American Camelid (SAC) (Lama gunacoa, Lama glama, Lama pacos Vicuna vicuna), guinea pig (Cavia porcellus), chinchilla (Chinchilla lanigera), turkey (Meleagris gallopavo) and duck (Cairina moschata, Anas platyrhynchos). These domesticated Neo-tropical animals have been reported in different locations. (2) To record the effects that these parasites have been reported to have had on the health and production of these animals.

\section{Materials and Method}

For the purpose of this review, reports and articles were searched for in scholarly publication databases (Google Scholar, PubMed and UWI linc). Search terms used were specific species names (e.g., Lama gunacoa, Lama glama, Lama pacos Vicuna vicuna, guinea pig (Cavia porcellus), chinchilla (Chinchilla lanigera), turkey (Meleagris gallopavo) and duck (Cairina moschata, Anas platyrhynchos) combined with the term endoparasites. Additional key terms such as "South American camelids" and "domesticated animal parasites" were also used. Searches were conducted from earliest available date in the database up to December 2018 and any other information was not presented in the review. All sources were assessed by the author for relevance, credibility and scientific inclusion to ensure the thoroughness and accuracy of review. Papers which focused on blood parasites or ectoparasites were not included in this review. Over 120 articles were retrieved but sixty-six articles were chosen for the body of this review based on relevance. The Sections 3-7 give information on the relevant Neo-tropical species. The section on South American Camelids was searched and twenty-five (25) articles were identified in the search. Of these twenty-five (25) papers only eleven (11) were relevant to endoparasites in these animals. The section on guinea pigs was searched using databases mentioned above and twenty (20) articles were identified in the search. Of these twenty articles (20) only thirteen (13) were relevant to endoparasites in these animals. The section on chinchillas was searched using databases mentioned above and fifteen (15) articles were identified in the search. Of these fifteen (15) papers only seven (7) were relevant to endoparasites in these animals. The section on turkeys was searched and thirty (30) articles were identified in the search. Of these thirty (30) papers only fifteen (15) were relevant to endoparasites in these animals. The final section which was done on turkeys was searched and thirty (30) articles were identified in the search. Of these thirty (30) papers only eighteen (18) were relevant to endoparasites in these animals.

\section{South American Camelids (Lama gunacoa, Lama glama, Lama pacos, Vicuna vicuna)}

Digestive tracts of Camelids in South America were analysed and Graphinema auchenia, Nematodirus lamae and Spiculopteragia peruviana was observed [18]. The following parasites were also identified; Camelostrongylus spp., Ostertagia spp., Teladorsagia spp., Marshallagia spp., Haemonchus spp., Trichostrongylus spp., Nematodirus spp., Capillaria spp., Cooperia spp., Bunostomum spp., Chabertia spp., Lamanema spp., Strongyloides spp., Oesophogostamum spp., Trichuris spp. and Skrjabinema spp. Trematodes included Fasciola hepatica, Fascioloides magna and Dicrocoelium dendriticum. Moniezia spp. was the only cestode mentioned. Intestinal protozoa found were Cryptosporidium spp., Gardia spp. and Eimeria spp. [18,19]. Lamas were classified as New World Camelid (NWC), at present they were distributed throughout the world but these animals originated in South America. Parasitic organisms 
found in these animals cause severe clinical disease. In England and Wales parasitic gastroenteritis (PGE), fascioliasis, coccidiosis and cryptosporidiosis were the major causes of gastrointestinal health problems [20]. Bunostomum, Camelostrongylus, Capillaria, Trichostrongylus, Cooperia, Nematodirus, Ostertagia, Marshallagia and Trichuris spp. was found in the stomach and intestines of NWC in England and Wales. Pathological lesions such as inflammation of the 3rd compartment of the stomach (acid pepsin stomach), enlarged mesenteric lymph nodes, subcutaneous oedema, ascites, hydrothorax and pulmonary oedema were found in lamas which had the gastrointestinal protozoa and helminths [20]. In Wisconsin a case of a young lama with unformed stool and poor condition was reported. Faecal examination revealed a few strongyles, Nematodirus spp. and Giardia cysts [21].

In Britain, two clinical cases of llamas (Lama glama) aged four (4) month and eight (8) were reported to have had diarrhoea, weight loss and subsequently died. Faecal examination found Camelostrongylus mentalatus and Trichostrongylus spp. in the third compartment of the stomach. In the large intestines Nematodirus_like eggs, Trichuris_like worms, Eimeria macusaniensis and Eimeria spp. [22]. In Chile, Nematodirus spp., Eimeria macusaniensis and Strongylida-like eggs were found in the faeces of llamas reared in semi-captivity. The animals' health or body condition was not reported in this study [23] (Table 1). Neonatal diarrheal in lamas and alpacas was reviewed and parasitic causes were found to be due to Cryptosporidium spp., Giardia duodenalis and Eimeria spp. [24]. In the southern United States from 2002-2013 lamas and alpacas were analysed for Haemonchus contortus. There was a prevalence of $42.6 \%$ in lamas and $22.2 \%$ in alpacas. There was a correlation between faecal egg count (FEC) and haematocrit, haemoglobin and red blood cells. Gross lesions seen included peritoneal, thoracic and pericardial effusions. Visceral pallor, subcutaneous oedema and serous atrophy of fat were also found [25]. South American Camlids were found to be infected with numerous Eimeria spp. Authors found the five most pathogenic species to be Emeria macusaniensis, Eimeria lamae, Eimeria alpacae, Eimeria punoensis and Eimeria ivataensis. With Eimeria macusaniensis considered as the most pathogenic species for South American Camelids [26].

Table 1. Gastrointestinal Parasites present in South American Camelids and its effect on the animals.

\begin{tabular}{|c|c|c|c|c|c|}
\hline Parasites & Location & $\begin{array}{l}\text { Pathological Lesions or } \\
\text { Clinical Effects }\end{array}$ & Confirmatory Test & Year & Ref. \\
\hline $\begin{array}{l}\text { Bunostomum, Camelostrongylus, } \\
\text { Capillaria, Trichostrongylus, } \\
\text { Cooperia, Nematodirus, Ostertagia, } \\
\text { Marshallagia Trichuris spp. }\end{array}$ & $\begin{array}{l}\text { England and } \\
\text { Wales }\end{array}$ & $\begin{array}{l}\text { enlarged lymph nodes, } \\
\text { subcutaneous oedema, } \\
\text { ascites, hydrothorax } \\
\text { pulmonary oedema }\end{array}$ & Necropsy & 2014 & [20] \\
\hline $\begin{array}{l}\text { Strongyles, Nematodirus spp., } \\
\text { Giardia spp. }\end{array}$ & Wisconsin & $\begin{array}{l}\text { unformed stool poor } \\
\text { condition }\end{array}$ & Coproscopy & 1987 & [21] \\
\hline $\begin{array}{c}\text { Camelostrongylus mentalatus } \\
\text { Trichostrongylus spp., } \\
\text { Nematodirus, Trichuris, Eimeria } \\
\text { macusaniensis Eimeria spp. }\end{array}$ & Britain & $\begin{array}{l}\text { diarrhoea, weight loss } \\
\text { and death }\end{array}$ & Necropsy & 2008 & [22] \\
\hline $\begin{array}{l}\text { Nematodirus spp., Eimeria } \\
\text { macusaniensis, Strongylida }\end{array}$ & Chile & Not recorded & Coproscopy & 2012 & [23] \\
\hline
\end{tabular}

The use of fenbendazole as an anthelmintic showed to have no adverse effects on the llamas' health at $5 \mathrm{mg} / \mathrm{kg}$. Reduction of faecal egg load was observed for Strongyloides, Trichuris and Nematodirus as compared to the control group [27]. Lamas and alpacas in Belgium were treated with ivermectin and showed no sign of clinical illness at $0.2 \mathrm{mg} / \mathrm{kg}$. The results showed that there was a $100 \%$ reduction in faecal egg count for Oesophagostomum spp. and Trichostrongylus spp. [28]. Reduction of coccidiosis can be attained through good management practices and maintenance of hygienic facilities. Strategic use of anticoccidials on a heard basis can be done. Anticoccidials used included decoquinate at $0.5 \mathrm{mg} / \mathrm{kg} /$ day for 28 days, amprolium at $5 \mathrm{mg} / \mathrm{kg} /$ day for 21 days. Ionophore antibiotics such as salinomycin and monensin should not be used as they were reported to be toxic in camels $[19,24]$ (Table 2). The effect of parasitic treatment on the performance of weaning alpaca 
was investigated. It was noted that animals which were dewormed performed worse than animals that were not dewormed. This information was preliminary but is does shed light on the role these organisms may play in the digestive tract of the animal [29].

Table 2. Drugs used in the Treatment of endoparasites in Non-Domesticated Neo-Tropical Animals.

\begin{tabular}{cccc}
\hline Host & Drug & Parasite & Ref. \\
\hline $\begin{array}{c}\text { South American Camalids } \\
\text { (Lamas) }\end{array}$ & Fenbendazole $(5 \mathrm{mg} / \mathrm{kg})$ & $\begin{array}{c}\text { Trichuris spp., } \\
\text { Strongyloides spp., } \\
\text { Nematodirus spp. }\end{array}$ & [27] \\
\hline Lamas and alpacas & Ivermectin $(0.2 \mathrm{mg} / \mathrm{kg})$ & $\begin{array}{c}\text { Oesophagostomum spp., } \\
\text { Trichostrongylus spp. }\end{array}$ & [28] \\
\hline Lamas & $\begin{array}{c}\text { Decoquinate }(0.5 \mathrm{mg} / \mathrm{kg}) \\
\text { Amprolium }(5 \mathrm{mg} / \mathrm{kg})\end{array}$ & Coccidia & {$[19,24]$} \\
\hline Guinea pigs & Sulphaquinalones & Eimeria caviae & [30] \\
\hline Guinea pigs & Piperazine & Paraspidodera uncinata & [31] \\
\hline $\begin{array}{c}\text { Mule ducks (F } \mathrm{F}_{1} \text { Anas platyrhynchos } \\
\text { and Cairina moschata) }\end{array}$ & Toltrazuril & Eimeria mulardi & [32] \\
\hline
\end{tabular}

\section{Guinea Pigs (Cavia porcellus)}

Caecal flagellates were found in the normal fauna of the guinea pig and treatment to remove these organisms may not have an effect on the animal. These caecal flagellates included Caviomonas mobilis, Chilomastix intestinalis, Chilomastix wenrichi, Chilomitus caviae, Chilomitus conexus, Enteromonas caviae, Hexamastix caviae, Hexamastix robustus and Tritrichomonas caviae [33]. Protozoa in the gastrointestinal tract which were reported to have caused disease included: Giardia duodenalis, Cryptosporidium wrairi, Eimeria caviae and Balantidium caviae. Helminths reported to have caused clinical disease included Fasciola spp. and Paraspidodera uncinata. Clinical disease included weight loss, debilitation and diarrhoea [33]. Helminths which were reported to be non-clinical included Trichuris gracilis, Capillaria hepatica, Viannella travassosi, Graphidiodes mazzai, Pseudoquinqueserialis caviae, Taxorchis caviae, Taxorchis ringueleti, Anoplocephala spp. and Monoecocestus parcitesticulatus [33].

In Peru, wild guinea pigs were examined in three localities in the Andean Highlands. Capillaria hepatica, Graphidoides mazzai, Trichuris gracilis, Paraspidodera uncinata and Fasciola hepatica was found in the gastrointestinal tract however no reference to the animals' body condition or body weight was recorded [34]. In Brazil worm burdens were compared in guinea pigs conventionally and openly reared. Guinea pigs in the study ranged from $240 \mathrm{~g}$ to $1000 \mathrm{~g}$. Animals reared conventionally had $10 \%$ prevalence of Paraspidodera uncinata while those reared openly had $40 \%$ prevalence [35].

In Italy, pet guinea pigs were analysed for endoparasites using faecal samples. Intestinal parasites found included Nippostrongylus-like eggs, Paraspidodera uncinata and Eimeria caviae [36]. In Italy faeces of pet rodents were sampled for Hymenolepis spp. The survey sampled sixty (60) guinea pigs and all were free of Hymenolepis spp. using floatation techniques [37]. Laboratory guinea pigs which were housed with rabbits were randomly tested for gastrointestinal parasites. Guinea pigs had Paraspidodera uncinata and Balantidium coli. Guinea pigs used in this study had similar weights $(600 \mathrm{~g})$ but no record of the body condition or clinical history of the animals was given [38]. Faecal samples of pet guinea pigs were analysed using polymerase chain reaction (PCR) in Europe for molecular typing of Giardia spp. Upon analysis $4 \%$ of the animals sampled were positive for Giardia spp. [39].

In the Congo, guinea pigs are farmed as a source of meat for rural villages. Mortalities were found to be highest for the first week of the guinea pig's life and more than half of the deaths were due to parasitic diseases. The two gastrointestinal parasites that were found to be the cause of the mortality in young guinea pigs were Balantidium coli and Eimeria spp. [40]. In the Highlands of Cameroon farmed guinea pigs and guinea pigs housed at teaching centres were tested for endoparasites. The study found 
Graphydium strigosum, Trichostrongylus spp. and Paraspidodera uncinata in guinea pigs reared on farm. At the teaching centres Eimeria caviae and Paraspidodera uncinata were identified using faecal floatation techniques. However, this study failed to record the body weights or body condition of the animals' sampled [41] (Table 3).

In rural villages in Bolivia small scale mixed farming systems are used as the main source of meat protein for rural villages. The major concern reported was that of theft and were reported to be problem free [42]. In these villages the Guinea-pig provides meat and a flexible source of income. Mortality in this study was attributed to inadequate nutrition [43]. Eimeria caviae, Cryptosporidium wraira and Balantidium coli was reported to be found in guinea pigs and have low pathogenic effect. Paraspidodera uncinata has been reported to be found in guinea pigs but treatment included use of piperazine [31]. Eimeria caviae has been reported to cause haemorrhagic diarrhoea in South America. Recommended treatment for coccidian in guinea pigs included to the use of sulphaquinalones [30] (Table 2). In Australia, guinea pigs were necropsied and lung and intestinal tissue were analysed. Using faecal floatation techniques Cryptosporium was identified in $24 \%$ of the animal samples. Molecular analysis using Polymerase Chain Reaction (PCR) was used and C. homai was the species identified [44].

Table 3. Gastrointestinal Parasites present in Guinea pigs and its effect on the animals.

\begin{tabular}{|c|c|c|c|c|c|}
\hline Parasites & Location & $\begin{array}{l}\text { Pathological Lesions or } \\
\text { Clinical Signs }\end{array}$ & $\begin{array}{l}\text { Confirmatory } \\
\text { Test }\end{array}$ & Year & Ref. \\
\hline $\begin{array}{c}\text { Capillaria hepatica, Graphidoides mazzai, } \\
\text { Trichuris gracilis, Paraspidodera uncinata, } \\
\text { Fasciola hepatica }\end{array}$ & Chile & Not Recorded & Necropsy & 2002 & [34] \\
\hline Paraspidodera uncinata & Brazil & Not recorded & Necropsy & 2002 & [35] \\
\hline $\begin{array}{c}\text { Nippostrongylus spp., Paraspidodera } \\
\text { uncinata Eimeria caviae }\end{array}$ & Italy & Not recorded & Coproscopy & 2015 & [36] \\
\hline Paraspidodera uncinata, Balantidium coli & Iran & Not Recorded & Coproscopy & 2014 & [38] \\
\hline $\begin{array}{l}\text { Graphydium strigosum, Trichostrongylus } \\
\text { spp., Paraspidodera uncinata, Eimeria caviae }\end{array}$ & Congo & Not Recorded & Coproscopy & 2015 & [41] \\
\hline
\end{tabular}

\section{Chinchillas (Chinchilla lanigera)}

In Europe, faecal samples of chinchillas were collected by veterinarians. The samples were positive for Giardia Assemblage A and B which causes clinical illness in humans [39]. In Italy rodents were surveyed for gastrointestinal parasites and Hymenolepis spp. was found in $25 \%$ of chinchillas sampled [36]. Chinchillas reared in Italian breeding facilities were sampled for Giardia duodenalis infection. The results showed Giardia duodenalis assemblage B and C was present using molecular techniques. The survey was conducted to evaluate the risk of zoonotic diseases but the health of the animals or body condition of the animals was not recorded [45]. In China faecal samples from pet chinchillas were analysed. Genotyping of Giardia duodenalis found assemblage A and B using molecular techniques [46].

In Chile, Giardia spp. was found in chinchillas of both commercial breeding facilities and natural reserve. The animals held at the reserve had a higher prevalence of Giardia spp. as compared to the commercial breeding farm. The faecal samples that were analysed were not given with prior clinical history or body condition of the animals [47]. In Brazil captive chinchillas were sampled for gastrointestinal parasites. These animals had no previous history of gastrointestinal illness but only Giardia spp. was identified in $8 \%$ of the samples [48].

In Belgium, pet chinchillas and breeding animals were sampled for the presence of Giardia duodenalis. Faecal samples were analysed using faecal floatation and molecular techniques but the animals' clinical history or body condition were not taken. The study found $66.3 \%$ positive for Giardia duodenalis with the predominant assemblage being B with assemblages C, A and E also present [49]. A similar study was done in Brazil with respect to the prevalence of Giardia duodenalis from exotic and 
wild animals kept in captivity. Chinchillas were found to be positive for Giardia duodenalis assemblage $\mathrm{B}$ which is zoonotic. All animals were asymptomatic for gastrointestinal illness [50]. In Argentina, in a fourteen-year study on fatal illness of captive chinchillas were performed. Gastrointestinal parasites found were Giardia spp., Eimeria spp., Trichostrongylus spp., Trichuris spp., Cryptosporidium spp. and Saccharomyces glutauratus. The authors noted that these parasites were not present in sufficient number to have caused death or illness [51] (Table 4). A similar study was done in Brazil but lasted for four years. Two hundred and two cases were examined and only one case of Giardia infection was attributed to death [52].

Table 4. Gastrointestinal Parasites present in Chinchillas and its effect on the animals.

\begin{tabular}{|c|c|c|c|c|c|}
\hline Parasites & Location & $\begin{array}{l}\text { Pathological Lesions } \\
\text { or Clinical Signs }\end{array}$ & Confirmatory Tests & Year & Ref \\
\hline Giardia Assemblage A, B & Europe & Not Recorded & $\begin{array}{l}\text { Coproantigen } \\
\text { analysis }\end{array}$ & 2014 & {$[39]$} \\
\hline Giardia Assemblage B, C & Italy & Not Recorded & $\begin{array}{l}\text { Direct Fluorescent } \\
\text { Assays and Genetic } \\
\text { Sequencing }\end{array}$ & 2012 & [44] \\
\hline Hymenolepis spp. & Italy & Not Recorded & Coproscopy & 2015 & [36] \\
\hline $\begin{array}{c}\text { Giardia duodenalis } \\
\text { Assemblage B, C, A, E }\end{array}$ & Belgium & Not Recorded & $\begin{array}{l}\text { Coproantigen } \\
\text { Analysis }\end{array}$ & 2011 & [49] \\
\hline Giardia duodenalis Assemblage B & Brazil & $\begin{array}{c}\text { No clinical signs for } \\
\text { gastrointestinal illness } \\
\text { was observed }\end{array}$ & $\begin{array}{l}\text { Coproantigen } \\
\text { analysis }\end{array}$ & 2011 & [50] \\
\hline $\begin{array}{l}\text { Giardia spp., Eimeria spp., } \\
\text { Trichostrongylus spp., Trichuris } \\
\text { spp., Cryptosporidium spp., } \\
\text { Saccharomyces glutauratus }\end{array}$ & Argentina & $\begin{array}{l}\text { No illness or deaths } \\
\text { were observed }\end{array}$ & Necropsy & 2017 & {$[51]$} \\
\hline
\end{tabular}

\section{Turkeys (Meleagris gallopavo)}

In Philadelphia, gastrointestinal samples were taken from wild turkeys and three cestodes were identified. There were Davainea ransomi, Davainea fuhrinanni and Metroliasthes lucida [53]. In Pennsylvania, wild turkeys (Melegradis gallopavo silvestris Vieollot) were surveyed for protozoan parasites. The species of gastrointestinal protozoa encountered were Eimeria meleagridis, Histomonas meleagridis and Trichomonas spp. No information on the body condition or live weight of the wild turkeys sampled were taken, therefore the effect of these protozoan parasites on wild turkey populations were unknown [54].

In Florida, wild turkeys were examined for helminths at different locations. The study revealed ten (10) trematodes, six (6) cestodes, seventeen (17) nematodes and one (1) acanthocephalan. Trematodes identified were: Echinoparyphium recurvatum, Zygocotyle lunata, Stomylotrema vivarium, Strigea elagans meleagris, Prostogonimus ovatus, Echinostoma revolutum, Ascocotyle spp., Brachylaima virginianum, Tanaisia spp. and Zonorchis spp. [55]. Cestodes found were: Metroliasthes lucida, Raillietina geogiensis, Raillietina ransomi, Raillietina cesticillus, Davainea meleagridis and Hymenolepsis carioca [54]. Nematodes recorded were: Strongyloides spp., Trichostrongylus tenuis, Dispharynx nasuta, Cyrnea eurycerca, Ascaridia dissimilis, Capillaria spp., Cyrnea spp., Singhfilaria hayesi, Heterakis gallinarum, Aproctella stoddardi, Synlimantus spp., Aulonocephalus pennula, Capillaria spp., Chandlerella spp., Cheilospirura spinose, Splendidofliaria spp. and Slendidofilariinae [55]. The one acanthocephalan observed was Mediohynchus papillosum. The authors did not record the live-weight or body condition of the wild turkeys to investigate the effect of the parasites on the wild turkeys [56].

In southern United States, wild turkeys (Meleagradis gallopovo) were analysed for the presence of gastrointestinal helminths. The study found four species of trematodes which were: Brachylaema virginiana, Cotylurus flabelliformis, Echinoparyphium recurvatum and Zygocotyle lunata. Eight species of cestodes were identified: Davainea meleagradis, Hymenolepis cantaniana, Hymenolepis carioca, Hymenolepis 
spp., Metroliasthes lucida, Raillietina georgiensis, Raillietina williamsi and Raillietina ransomi. [53] Thirteen species of nematodes were identified: Ascaridia dissimilis, Ascaridia galli, Capillaria annulata, Capillaria bursata, Capillaria obsignata, Dispharynx nasuta, Gongylonema ingluvicola, Heterakis gallinae, Seurocyrnea colini, Seurocyrnea spp., Strongyloides avium, Strongyloides spp. and Trichostrongylus tenuis. However, no records were presented on the body condition or body weight of the wild turkeys that were sampled [56]. In Kentucky and Tennessee gastrointestinal tracts were taken from wild turkeys. Parasites collected from these wild birds were Hymenolepis carioca, Metroliasthes lucida, Raillietina georgensis, Raillietina williamsi, Ascaridia dissimilis, Capillaria caudinflata and Heterakis gallinarum. All animals' samples that were collected did not include the animals' body condition or health status [57].

Pen-raised wild turkeys were surveyed for coccidian parasites, gastrointestinal samples were taken but no information was recorded on the weight, body condition or clinical history of the sampled birds. The observations revealed Eimeria meleagrimitis, Eimeria gallopavonis, Eimeria meleagridis, Eimeria dispersa, Eimeria innocua-Eimeria subrontunda and an undescribed coccidian species [58]. Wild turkeys in Arkansas were sampled for infectious disease organisms. Neither the live-weight nor body condition of turkeys sampled were recorded. Enteric parasites found were Ascaridia dissimilis, Heterakis gallinarum, Eimeria dispersa and Raillietina spp. [59]. Juvenile and adult turkeys in eastern Kansas were sampled for enteric helminths. The animals which were collected were eviscerated and the contents stored in formalin. However, the body weight or body condition was not recorded. The parasites that were found included; Echinoparyphium recurvatum, Echinostoma revolutum, Metroliasthes lucida, Imparmargo baileyi, Railletiena spp., Choanataenia spp., Mediorhynchus grandis and Heterakis gallinarum [60].

In Brazil, free range turkeys were sampled for gastrointestinal parasites. The birds sampled showed no clinical sign of disease and had weights ranging from $2.2 \mathrm{~kg}$ to $8.87 \mathrm{~kg}$. Helminths found were Cheilospirura hamulosa, Heterakis gallinarum, Baruscapillaria obsignata, Eucoleus annulatus, Hymenolepis cantaniana and Raillietina tetragona. Microscopic lesions of the gastrointestinal tract included intense chronic diffuse inflammation mixed granulocyte inflammation extended to the muscular layer [61-64].

In Nebraska, wild turkeys were surveyed for infectious disease. Samples taken were visceral organ but body condition or live-weight was not recorded. Cestodes found included: Choanotaenia infundibulum, Davainea meleagridis, Echinolepsis carioca, Fimbriaria fasciolaris, Microsomacanthus paracompressa, Raillietina circumvallata, Raillietina cestillus, Raillietina echinoborthida, Raillietina ransomi, Raillietina tetragona, Raillietina williamsi and Sobolevicanthus gracilis [64]. Nematodes identified were Ascaridia dissimilis, Ascaridia galli, Capillaria bursata, Capillaria caudinflata, Capillaria annulatus, Eucoleus annulatus, Ganguleterakis dispar, Heterakis gallinarum, Syngamus trachea, Thominx phasiania and Trichostrongylus tenuis [65]. Trematodes recorded were Echinoparyphium recurvatum, Echinoparypium rubrum, Echinostoma revolutum, Echinostoma trivolis, Notocotylus attenuatus, Prosthogonimus cuneatus and Prostogonimus ovatus. The one acanthocephalan observed was Mediorynchus spp. [65].

Turkey poults from farms experiencing diarrhoea, depression and huddling were sampled. The causative agent was Cryptosporidium spp. Present in the enterocytes of the middle and lower small intestine. Affected poults showed villous atrophy, crypts that were hypertrophied and reduction in total mucosal thickness [66]. In Iowa commercial turkeys were sampled and Cryptosporidium oocyst was found in $80 \%$ of seventeen day old turkeys and 38\% in twenty-four day old turkeys. Birds were not clinically ill from the pathogen and no histological lesions were observed except for displacement of micro-villi at attachment sites [67] (Table 5). Wild male turkeys were infected with coccidia to observe the effect on plumage coloration. Turkeys were infected with Eimeria adenoids, Eimeria gallogavonis, Eimeria meleagramitis and Eimeria dispersa. Results showed turkeys infected with coccidia had plumage coloration that was duller than un-infected group [68]. 
Table 5. Gastrointestinal Parasites present in Turkeys and its effect on the animals.

\begin{tabular}{|c|c|c|c|c|c|}
\hline Parasites & Location & $\begin{array}{l}\text { Pathological Lesions or } \\
\text { Clinical Signs }\end{array}$ & Confirmatory Test & Year & Ref. \\
\hline Davainea ransomi, Davainea fuhrinanni, Metroliasthes lucida & Philadelphia & Not Recorded & Necropsy & 1931 & [53] \\
\hline Eimeria meleagridis, Histomonas meleagridis, Trichomonas spp. & Philadelphia & Not Recorded & Coproscopy & 1948 & [54] \\
\hline $\begin{array}{l}\text { Echinoparyphium recurvatum, Zygocotyle lunata, Stomylotrema vivarium, Strigea elagans meleagris, Prostogonimus ovatus, } \\
\text { Echinostoma revolutum, Ascocotyle spp., Brachylaima virginianum, Tanaisia spp., Zonorchis spp., Metroliasthes lucida, } \\
\text { Raillietina geogiensis, Raillietina ransomi, Raillietina cesticillus, Davainea meleagridis, Hymenolepis carioca, Strongyloides } \\
\text { spp., Trichostrongylus tenuis, Dispharynx nasuta, Cyrnea eurycerca, Ascaridia dissimilis, Capillaria spp., Cyrnea spp., } \\
\text { Singhfilaria hayesi, Heterakis gallinarum, Aproctella stoddardi, Synlimantus spp., Aulonocephalus pennula, Capillaria spp., } \\
\text { Chandlerella spp., Cheilospirura spinose, Splendidofliaria spp., Slendidofilariinae. Mediohynchus papillosum }\end{array}$ & Florida & Not Recorded & Necropsy & 1975 & [55] \\
\hline $\begin{array}{l}\text { Brachylaema virginiana, Cotylurus flabelliformis, Echinoparyphium recurvatum, Zygocotyle lunata. Davainea meleagradis, } \\
\text { Hymenolepis cantaniana, Hymenolepis carioca, Hymenolepis spp., Metroliasthes lucida, Raillietina georgiensis, Raillietina } \\
\text { williamsi, Raillietina ransomi, Ascaridia dissimilis, Ascaridia galli, Capillaria annulata, Capillaria bursata, Capillaria obsignata, } \\
\text { Dispharynx nasuta, Gongylonema ingluvicola, Heterakis gallinae, Seurocyrnea colini, Seurocyrnea spp., Strongyloides avium, } \\
\text { Strongyloides spp., Trichostrongylus tenuis }\end{array}$ & United States & Not Recorded & Necropsy & 1963 & [56] \\
\hline $\begin{array}{l}\text { Hymenolepis carioca, Metroliasthes lucida, Raillietina georgensis, Raillietina williamsi, Ascaridia dissimilis, Capillaria } \\
\text { caudinflata, Heterakis gallinarum }\end{array}$ & $\begin{array}{l}\text { Kentucky } \\
\text { Tennessee }\end{array}$ & Not Recorded & Necropsy & 1984 & {$[57]$} \\
\hline Eimeria meleagrimitis, Eimeria gallopavonis, Eimeria meleagridis, Eimeria dispersa, Eimeria innocua-Eimeria subrontunda & United States & Not Recorded & Coproscopy & 1988 & [58] \\
\hline Ascaridia dissimilis, Heterakis gallinarum, Eimeria dispersa, Raillietina spp. & Arkansas & Not Recorded & Coproscopy & 1990 & [59] \\
\hline $\begin{array}{l}\text { Echinoparyphium recurvatum, Echinostoma revolutum, Metroliasthes lucida, Imparmargo baileyi, Railletiena spp., } \\
\text { Choanataenia spp., Mediorhynchus grandis, Heterakis gallinarum }\end{array}$ & Kansas & Not Recorded & Necropsy & 2003 & [60] \\
\hline $\begin{array}{l}\text { Cheilospirura hamulosa, Heterakis gallinarum, Baruscapillaria obsignata, Eucoleus annulatus, Hymenolepis cantaniana and } \\
\text { Raillietina tetragona }\end{array}$ & Brazil & $\begin{array}{l}\text { Chronic diffuse } \\
\text { inflammation with } \\
\text { granulocyte infiltration } \\
(2.2-8.8 \mathrm{~kg} \mathrm{LW})\end{array}$ & Necropsy & 2006-2008 & [61-64] \\
\hline $\begin{array}{l}\text { Choanotaenia infundibulum, Davainea meleagridis, Echinolepsis carioca, Fimbriaria fasciolaris, Microsomacanthus } \\
\text { paracompressa, Raillietina circumvallata, Raillietina cestillus, Raillietina echinoborthida, Raillietina ransomi, Raillietina } \\
\text { tetragona, Raillietina williamsi and Sobolevicanthus gracilis, Ascaridia dissimilis, Ascaridia galli, Capillaria bursata, Capillaria } \\
\text { caudinflata, Capillaria annulatus, Eucoleus annulatus, Ganguleterakis dispar, Heterakis gallinarum, Syngamus trachea, } \\
\text { Thominx phasiania, Trichostrongylus tenuis, Echinoparyphium recurvatum, Echinoparypium rubrum, Echinostoma revolutum, } \\
\text { Echinostoma trivolis, Notocotylus attenuatus, Prosthogonimus cuneatus Prostogonimus ovatus, Mediorynchus spp. }\end{array}$ & Nebraska & Not Recorded & Necropsy & 2005 & {$[65]$} \\
\hline Cryptosporidium spp. & Missouri & $\begin{array}{l}\text { Huddling, diarrhoea, } \\
\text { villous atrophy, cryptic } \\
\text { hypertophy }\end{array}$ & Coproscopy & 1988 & [66] \\
\hline Cryptosporidium spp. & Iowa & $\begin{array}{l}\text { No clinical illness or } \\
\text { lesions }\end{array}$ & Coproscopy & 1988 & {$[67]$} \\
\hline
\end{tabular}




\section{Ducks (Cairina moschata, Anas platyrhynchos, Dendrocyga autumnalis)}

In the black bellied whistling duck (Dendrocyga autumnalis) in Southern Texas a wide range of parasites were identified in the gastrointestinal tract. Echinuria uncinata, Tropisursus crami, Parhadjelia neglecta, Anomotaenia spp., Apatemon gracilis, Zygocotyle lunata, Porrocaecum spp., Corynosoma spp., Corynosoma peposacae, Dicranotaenia spp., Echinostoma revolutum, Sobolevicanthus spp. and Cloacataenia megalops were identified but seemed to have no effect on the ducks' physical condition [69]. In Egypt different breeds of ducks were analysed for gastrointestinal parasites. Ascaridia galli, Heterakis gallinarum, Cladogynia phoeniconaiadis, Echinolepis carioca, Baerfainia anoplocephaloides, Echinoparyphium paraulum, Echinoparyphium recurvatum and Entamoeba gallinarum were found in a wide range of ducks [70].

In Tanzania, parasites of free range adult ducks were identified. The parasites reported to have been identified were Ascaridia coluba, Ascaridia dissimilis, Ascaridia galli, Capillaria anatis, Capillaria annulata, Capillaria contorta, Heterakis dispar, Heterakis gallinarum, Raillietina echinoborthrida, Raillietina tetragona, Subulura brumpti, Subulura sucturia [71]. The author stated potentially pathogenic worms such as Ascaridia galli and Heterakis gallinarum had no clear physical effect on the health status of the ducks [70]. Similar work was done in free ranging ducks in Kenya. Parasites found and included; Gongylonema ingluvicola, Heterakis gallinarum, H. isolonche, Capillaria contorta, Sublura brumpti, Ascaridia galli and Hymenolepis spp. [72].

In Eastern Kenya, muscovy ducks at different locations were slaughtered and the presence of endoparasites investigated. The investigation found the following; Ascaridia galli, Trichostrongylus tenus, Heterakis gallinarum, Sublura brumpti, Capillaria contorta, C. annulata, Tetrameres fissipina, Raillietina echinoborthida, R. tetragona and Hymenolepis cantaniana [73]. In Southwestern Nigeria gastrointestinal parasites that inhabited the domestic duck (Anas platrhynchos) was studied. The study revealed the following parasites; Ascaridia galli, Heterakis gallinarum, Capillaria spp., Syngamus trachea, Echinuris uncinata, Tyzzeria spp., Eimeria spp. and Cryptosporidium spp. Although numerous parasites were found no quantification was made and no information was presented on the body condition of the animal pre- or post mortem [74].

In central Mexico and the south-western United States twenty-five species of helminths were recovered from the gastrointestinal trach of the wild Mexican duck (Anas platyrhynchos diazi) [75]. The parasites recorded were; Echinopartphium recurvatum, Echinostoma revolutum, Hypoderaeum conoideum, Notocotylus attenuatus, Prosthogonimus cuneatus, Zygocotyle lunata, Anomotaenia ciliate, Cloacataenia megalops, Diorchis bulbodes, Diorchis spp., Drepanidotaenia lanceolata, Echinocotyle rosseteri, Fimbriaria fasciolaris, Fimbriaroides spp., Hymenolepis spp. (1), Hymenolepis spp. (2), Sobolevicanthus gracilis, Corynosoma constrictum, Polymorphus minutus, Amidostomum acutum, Echinuria spp., Epomidostomum crami, Hystrichis varispinosus, Tetrameres spp. and Rusguniella arctica [76]. A similar study on wild ducks (Anas platyrhynchos diazi) in Mexico was done for identification of helminths. Eight species of helminths were identified and included; Zygocotyle lunata, Echinostoma revolutum, Psilostromum ondatrae, Amidostomum anseris, Capillaria spp., Corynosoma spp., Polymorphus boschadis and Hymenolepis megalops. However, no data was provided on the body condition or the live-weight of the ducks which harbored these parasites [76].

In the Czech Republic, the mallard duck (Anas platyrhynchos) is reared on breeding farms were sampled for gastrointestinal parasites. The study found a low prevalence of gastrointestinal parasites in ducks and coccidia and Amidostomum anseris were the only parasites found [77]. In Bangladesh, the domestic duck (Anas platyrhynchos) and the Muscovy duck (Cairina moschata) were evaluated for gastrointestinal parasites. The domestic duck had Ascaridia spp., Heterakis spp., Capillaria spp. and Eimeria spp. The Muscovy duck had only Eimeria spp. and Ascaridia spp. [78]. Similar work was done in Japan with anseriforms which lived in the wild. The six parasites found in ducks (Anas platyrhynchos) and included; Tetrameres fissipina, Streptocara crassicauda, Epomidostomum crami, Amidostomum anseris, Capillaria anatis and Eocoleus contortus but no correlation was made between the presence of the parasites and the body condition of the ducks [79]. Seven parasites were reported to have been found 
in the gastrointestinal tracts of mallard duck (Anas platyrhynchos). The parasites involved were as followed; Echinostoma revolutum, Hymenolepis spp., Cotylurus formis, Tetrameres spp., Zygocotyle spp., Amphirus elongatus and Filicollis spp. but no records of the animals' body condition or weights were given [80].

The effects of Histomonas meleagridis on the performance of Muscovy ducks (Cairina moschata) and mule ducks ( $\mathrm{F}_{1}$ Cairina moschata and Anas platyrhynchos) was done experimentally. Authors reported that there was no difference in weight gain, mortality and clinical lesion between ducks infected and the control over at thirty-five-day period. These results showed that the ducks were resistant to clinical disease but can be used as carriers for the disease to susceptible species [81]. In Italy an outbreak of Streptocara incognita was reported in Muscovy ducks (Carina moschata domesticus). The infected ducks were in poor body condition with pectoral muscle atrophy. Streptocara incognita was found in the oesophagus and caused dilation and discrete diphtheric lesion underneath a pseudo membrane. Post-mortem examination revealed pseudo membrane oesophagitis which occluded the lumen of the oesophagus [82].

Cryptosporidium spp. has been found in farmed ducks in Germany. The reports showed that there were no correlations between the presence of Cryptosporidium and poor performance, clinical signs of ill health or gastrointestinal lesion [83] (Table 6). Cochlosoma rostratum can be found in many domestic ducks (Anas platyrhynchos and Carina moschata) and was observed in sick and healthy birds. No difference was noted in the faeces and intestinal contents of parasitized and non-parasitized birds. Sick birds were cases of bacterial infection with heavy infection of Cochlosoma rostratum but inflammation of the digestive tract was absent [84]. Ducklings were experimentally infected with Coclosoma anatis to observe the effect of the parasite on the birds' performance. Results reported showed infection with Cochlosoma anatis did result in lower palatinase and maltase activity in the small intestine but Sucrase activity was significantly increased. However, there was no overt clinical sign of gastrointestinal illness or weight loss observed [85]. Ducklings (Cairina moschata) were inoculated with Cochlosoma anatis had lower mean body weights than the control group. Clinical observations and parasitological findings correlated Cochlosoma anatis as a possible cause for runting syndrome in ducklings [86]. The efficacy of Toltrazuril on Eimeria mulardi in mule ducks ( $\mathrm{F}_{1}$ Anas platyrhynchos and Cairina moschata) was investigated. Authors noted that treatment of infected ducks five days' post-inoculation received similar results as ducks (healthy) that were not exposed to Eimeria mulardi [32] (Table 2). 
Table 6. Gastrointestinal Parasites present in ducks and its effect on the animals.

\begin{tabular}{|c|c|c|c|c|c|}
\hline Parasites & Location & $\begin{array}{l}\text { Pathological Lesions or } \\
\text { Clinical Signs }\end{array}$ & Confirmatory Tests & Year & Ref. \\
\hline $\begin{array}{l}\text { Echinuria uncinata, Tropisursus crami, Parhadjelia neglecta, Anomotaenia spp., Apatemon gracilis, Zygocotyle lunata, } \\
\text { Porrocaecum spp., Corynosoma spp., Corynosoma peposacae, Dicranotaenia spp., Echinostoma revolutum, } \\
\text { Sobolevicanthus spp., Cloacataenia megalops }\end{array}$ & Texas & $\begin{array}{l}\text { No effect on duck's } \\
\text { physical condition }\end{array}$ & Necropsy & 1975 & [69] \\
\hline \multirow[t]{2}{*}{$\begin{array}{l}\text { Ascaridia galli, Heterakis gallinarum, Cladogynia phoeniconaiadis, Echinolepis carioca, Baerfainia anoplocephaloides, } \\
\text { Echinoparyphium paraulum, Echinoparyphium recurvatum, Entamoeba gallinarum }\end{array}$} & Egypt & Not Recorded & Necropsy & 2011 & [70] \\
\hline & Tanzania & $\begin{array}{l}\text { No clear physical effect on } \\
\text { the health }\end{array}$ & Necropsy & 2007 & [71] \\
\hline $\begin{array}{l}\text { Gongylonema ingluvicola, Heterakis gallinarum, H. isolonche, Capillaria contorta, Sublura brumpti, Ascaridia galli, } \\
\text { Hymenolepis spp. }\end{array}$ & Kenya & Not Recorded & Necropsy & 2018 & [72] \\
\hline $\begin{array}{l}\text { Ascaridia galli, Trichostrongylus tenus, Hetrerakis gallinarum, Sublura brumpti, Capillaria contorta, C.annulata, } \\
\text { Tetrameres fissipina, Raillietina echinoborthida, R. tetragona, Hymenolepsis cantaniana }\end{array}$ & Kenya & Not Recorded & Coproscopy & 2015 & [73] \\
\hline $\begin{array}{l}\text { Ascaridia galli, Heterakis gallinarum, Capillaria spp., Syngamus trachea, Echinuris uncinata, Tyzzeria spp., Eimeria } \\
\text { spp., Cryptosporidium spp. }\end{array}$ & Nigeria & Not Recorded & Coproscopy & 2011 & [74] \\
\hline $\begin{array}{l}\text { Echinopartphium recurvatum, Echinostoma revolutum, Hypoderaeum conoideum, Notocotylus attenuatus, } \\
\text { Prosthogonimus cuneatus, Zygocotyle lunata, Anomotaenia ciliate, Cloacataenia megalops, Diorchis bulbodes, Diorchis } \\
\text { spp., Drepanidotaenia lanceolata, Echinocotyle rosseteri, Fimbriaria fasciolaris, Fimbriaroides spp., Hymenolepis spp., } \\
\text { Sobolevicanthus gracilis, Corynosoma constrictum, Polymorphus minutus, Amidostomum acutum, Echinuria spp., } \\
\text { Epomidostomum crami, Hystrichis varispinosus, Tetrameres spp., Rusguniella arctica }\end{array}$ & Mexico and USA & Not Recorded & Necropsy & 1986 & [75] \\
\hline $\begin{array}{l}\text { Zygocotyle lunata, Echinostoma revolutum, Psilostromum ondatrae, Amidostomum anseris, Capillaria spp., } \\
\text { Corynosoma spp., Polymorphus boschadis, Hymenolepis megalops }\end{array}$ & Mexico & Not Recorded & Necropsy & 2010 & [76] \\
\hline Ascaridia spp., Heterakis spp., Capillaria spp., Eimeria spp. & Bangladesh & Not Recorded & Coproscopy & 2014 & [77] \\
\hline $\begin{array}{l}\text { Tetrameres fissipina, Streptocara crassicauda, Epomidostomum crami, Amidostomum anseris, Capillaria anatis, } \\
\text { Eocoleus contortus }\end{array}$ & Japan & Not Recorded & Necropsy & 2009 & [79] \\
\hline $\begin{array}{l}\text { Echinostoma revolutum, Hymenolepis spp., Cotylurus formis, Tetrameres spp., Zygocotyle spp., Amphirus elongates, } \\
\text { Filicollis spp. }\end{array}$ & Michigan & Not Recorded & Coproscopy & 1938 & [80] \\
\hline Streptocara incognita & Italy & Poor body condition & Copsroscopy & 2005 & [82] \\
\hline Cryptosporidium spp. & Germany & No signs of ill health & Coproscopy & 1994 & [83] \\
\hline
\end{tabular}




\section{Conclusions}

Generally, neo-tropical animals in the wild were observed as reservoirs of the parasites. Several authors paid little to any attention to the effect these parasites have on the animals' body condition and body weight. South American Camelids, ducks, chinchillas, turkeys and guinea pigs was found to have had numerous parasites present in their gastrointestinal tracts. However, these were only a few cases where these were observed to have been experiencing ill health due to gastrointestinal parasites. The animals in this review were found free ranging or in the wild and seemed to have the ability to harbour these parasites without any overt clinical effect. This can pose health risks to humans and introduce these parasites to domesticated livestock species. Further studies should be conducted to observe the effect gastrointestinal parasites have on production and health on Neo-tropical Domesticated animals (South American Camelids, ducks, chinchillas, turkeys and guinea pigs). The majority of the literature reviewed was reported in the last twenty years. This sheds light on the improved diagnostic technology as well as the recent interest in the endoparasites of these animals present in the wild.

Author Contributions: Conceptualization was done be K.R.J. and G.W.G.; Methodology and data collection was done by K.R.J. Writing-Original Draft Preparation was done by K.R.J. and G.W.G. Writing—Review \& Editing was done by K.R.J. and G.W.G.; Supervision was done by G.W.G.

Funding: This research was funded by Campus Research and Publication department of the University of the West Indies, St. Augustine Campus.

Acknowledgments: Members of Staff of the Alma Jordan Library at the University of the West Indies.

Conflicts of Interest: The authors declare no conflict of interest.

\section{References}

1. Dunlop, R.H.; Williamson, D.J. Veterinary Medicine: An Illustrated History; Mosby: New York, NY, USA, 1996.

2. Brown-Uddenberg, R.; Garcia, W.G.; Baptiste, Q.S.; Counand, T.; Adogwa, A.; Sampson, T. The Agouti (Dasyprocta leporina, D. agouti) Booklet and Production Manual; GWG Publications: St. Augustine, Trinidad, 2004.

3. Mollineau, W.M.; Sampson, T.; Adogwa, A.O.; Garcia, G.W. Anatomical Stages of Penile Erection in the Agouti (Dasyprocta leporina) Induced by Electro-Ejaculation. Anat. Histol. Embryol. 2012, 41, 392-394. [CrossRef] [PubMed]

4. Singh, M.D.; Adogwa, A.O.; Mollineau, W.M.; Garcia, G.W. Gross and microscopic anatomy of the reproductive tract of the female agouti (Dasyprocta leporina): A Neo-tropical rodent with potential for food production. Trop. Agric. (Trinidad) 2014, 9, 38-46.

5. Garcia, G.W.; Baptiste, Q.S.; Adogwa, A.O.; Kakuni, M.; Arishima, K.; Makita, T. The Digestive System of the Agouti (Dasyprocta leporina)-Gross Anatomy and Histology. Jpn. J. Zoo Wildl. Med. 2000, 5, 55-66. [CrossRef]

6. Dookie, B.; Jones, K.R.; Mohammed, R.; Garcia, G.W. Feed particle size preference and feed wastage in Agouti (Dasyprocta leporina) reared intensively in the Republic of Trinidad and Tobago. Livest. Res. Rural Dev. 2018, 30, 1-6.

7. Lall, K.R.; Jones, K.R.; Garcia, G.W. Nutrition of Six Selected Neo-Tropical Mammals in Trinidad and Tobago with the Potential for Domestication. Vet. Sci. 2018, 5, 52. [CrossRef] [PubMed]

8. Suepaul, R.; Charles, R.; Dziva, F. Aerobic microflora and endoparasites of freshly shot wild Agouti (Dasyprocta leporina) in Trindad, West Indies. J. Zoo Wildl. Med. 2016, 47, 1044-1048. [CrossRef] [PubMed]

9. Jones, K.R.; Garcia, G.W. A survey of the gastrointestinal parasites present in the Agouti (Dasyprocta leporina) reared intensively in Trinidad. Livest. Res. Rural Dev. 2017, 29, 1-7.

10. Jones, K.R.; Garcia, G.W. Observations on endoparasitic load in captive reared agoutis (Dasyprocta leporina) without anthelmintic exposure in Trinidad, Republic of Trinidad and Tobago. Livest. Res. Rural Dev. 2018, $30,1-7$.

11. Jones, K.R.; Lall, K.R.; Garcia, G.W. Haematological and Serum biochemical values of the agouti (Dasyprocta leporina) reared intensively in Trinidad, Republic of Trinidad and Tobago. Livest. Res. Rural Dev. 2019, 31, 1-8. 
12. Lall, K.R.; Jones, K.R.; Garcia, G.W. Infectious Diseases of Six Non-Domesticated Neo-Tropical Animals in Trinidad and Tobago. Int. J. Trop. Vet. Biomed. Res. 2018, 3. [CrossRef]

13. Tardieu, L.; Adogwa, A.O.; Garcia, G.W. Didelphis species, neo-tropical animals with the potential for intensive production: Part 1 Review of taxonomy, natural history, general biology, animal behaviour, and nutrition. Trop. Agric. 2017, 94, 157-174.

14. Soulsby, E.J. Helminths, Arthropods and Protozoa of Domesticated Animals; Lea \& Febiger: Philadelphia, PA, USA, 1968.

15. Urquhart, G.M.; Armour, J.; Duncan, J.L.; Dunn, A.M.; Jennings, F.W. Veterinary Parasitology, 2nd ed.; Blackwell Science: Cambridge, UK, 1996.

16. Hendrix, C.M.; Robinson, E.D. Diagnostic Parasitology for Veterinary Technicians-E-Book; Elsevier Health Sciences: Amsterdam, NY, USA, 2016.

17. Jones, K.R.; Garcia, G.W. Gastrointestinal parasites of domesticated animals introduced into the Neo-tropics (New World Tropics). Concepts Dairy Vet. Sci. 2018, 1. [CrossRef]

18. Franz, S.; Wittek, T.; Joachim, A.; Hinney, B.; Dodak, A.M. Llamas and alpacas in Europe: Endoparasites of the digestive tract and their phamacotherapeutic control. Vet. Rec. 2015, 204, 255-262. [CrossRef] [PubMed]

19. Fowler, M.E. Medicine and Surgery of South American Camelids: Llama, Alpaca, Vicuna, Guanaco; Iowa State University Press: Ames, IA, USA, 1998.

20. Tworney, D.E.; Wu, G.; Nicholason, R.; Watson, E.N.; Foster, T. Review of laboratory submission for New World camelids in England and Wales. Vet. Rec. 2014, 200, 51-59. [CrossRef]

21. Kiorpes, A.L.; Kirkpatrick, C.E.; Bowman, D.D. Isolation of Giardia form a llama and from a sheep. Can. J. Vet. Res. 1987, 51, 277-280. [PubMed]

22. Welchman, D.B.; Parr, J.G.; Wood, R.; Maed, A.M.S.; Starnes, A.F. Alpacas and llama nematodes in Britain. Vet. Rec. 2008. [CrossRef]

23. Correa, L.; Zapata, B. Gastrointestinal and blood parasite determination in the guanaco (Llama guanicoe) under semi-captivity conditions. Trop. Anim. Health Prod. 2012, 44, 11-15. [CrossRef] [PubMed]

24. Whitehead, C.; Anderson, D.E. Nematode diarrhoea and llamas and alpacas. Small Rumin. Res. 2006, 61, 207-215. [CrossRef]

25. Edward, E.E.; Garner, B.C.; Williamson, L.H.; Storey, B.E.; Sakamoto, K. Pathology of Haemonchus contortus in New World Camelids in Southern United State: A retrospective review. J. Vet. Diagn. Investig. 2016, 23, 105-109. [CrossRef] [PubMed]

26. Dubey, J.P. A review of coccidiosis in South American Camelids. Parasitol. Res. 2018, 117, 1999-2013. [CrossRef] [PubMed]

27. Beier, E., III; Lehenbauer, T.W.; Sangiah, S. Clinical efficacy of fenbendazole against gastrointestinal parasites in llamas. Small Rumin. Res. 2000, 36, 17-23. [CrossRef]

28. Geurden, T.; Van Hemelrijk, K. Ivermectin treatment against nematodes in New World camelids in Belgium. Small Rumin. Res. 2005, 58, 71-73. [CrossRef]

29. Thomas, S.M.; Morgan, E.R. Effect on performance of weanling alpacas following treatments against gastro-intestinal parasites. Vet. Parasitol. 2013, 198, 244-249. [CrossRef] [PubMed]

30. Francia, L.C. Manual Produccion de Cuyas; Instituto Nacional de Innovacion Agraria: Lima, Peru, 2014.

31. Wagner, J.E. Guinea pigs. In Handbook of Diseases of Laboratory Animals; Hime, M.J., O'donoghue, N., Eds.; Heinemann Veterinary Books: London, UK, 1979.

32. Reynaud, M.C.; Chauve, C.M.; Gastellu, J.; Gounel, J.M. Administration of toltrazuril during experimental coccidiosis in mule ducks: Comparison of the efficacy of a single administration at two different endogenous stages. Vet. Parasitol. 1999, 81, 265-274. [CrossRef]

33. Ballweber, L.R.; Harkness, J.E. Parasites of Guinea Pigs. In Flynn's Parasites of Laboratory Animals; Baker, D.E., Ed.; Blackwell Publishing: Ames, IA, USA, 2007.

34. Dittmar, K. Arthropods and Helminth Parasites of the Wild Guinea pigs, Cavia aperea, From the Andes and the Cordillera in Peru, South America. J. Parasitol. 2002, 88, 409-411. [CrossRef]

35. Pinto, R.M.; Gomes, D.C.; Muniz-Pereira, L.C.; Noronha, D. Helminths of guinnea pigs, Cavia porcellus (Linnaeus), in Brazil. Rev. Braz. Zool. 2002, 19, 261-269. [CrossRef]

36. d'Ovidio, D.; Noviello, E.; Ianniello, D.; Cringoli, G.; Rinaldi, L. Survey of endoparasites in pet guinea pigs in Italy. Parasitol. Res. 2015, 114, 1213-1216. [CrossRef] [PubMed] 
37. d' Ovidio, D.; Noviello, E.; Pepe, P.; Del Prete, L.; Cringoli, G.; Rinaldi, L. Survey of Hymenolepis spp. in pet rodents in Italy. Parasitol. Res. 2015, 114, 4381-4384. [CrossRef] [PubMed]

38. Motamedi, G.; Moharami, M.; Paykari, H.; Eslampanah, M.; Omraninava, A. A survey on the Gastrointestinal parasites of Rabbits and Guinea pigs in a Laboratory Animal House. Arch. Razi Inst. 2014, 69, 77-81.

39. Pantchev, N.; Broglia, A.; Paoletti, B.; Globokar Vrhovec, M.; Bertram, A.; Nockler, K.; Cacclo, M. Occurrence and molecular typing of Giardia isolates in pet rabbits, chinchillas, guinea pigs and ferrets collected in Europe during 2006-2012. Vet. Rec. 2014, 175, 18. [CrossRef] [PubMed]

40. Umba, J.M.; Kashala, J.C.K.; Ilaka, A.N.; Ngulu, A.N.; Tshikung, K.M.D.; Atangana, A.; Khasa, D. Mortality of young Guinea pigs (Cavia procellus) crossed and its main causes around Kinshasa, DR Congo. Livest. Res. Rural Dev. 2016, 28, 7.

41. Kouam, M.K.; Meutchieye, F.; Nguafack, T.T.; Miegoue, E.; Tchoumboue, J.; Theodoropoulos, G. Parasitic fauna of domestic cavies in the western highlands of Cameroon (Central Africa). BMC Vet. Res. 2015, 11, 288. [CrossRef] [PubMed]

42. Paterson, R.T.; Joaquin, N.; Chamon, K.; Palomino, E. The productivity of a Small Animal Species in Small-scale Mixed Farming Systems in Subtropical Bolivia. Trop. Anim. Health Prod. 2001, 33, 1-14. [CrossRef] [PubMed]

43. Manjeli, Y.; Tchoumboue, J.; Njwe, R.M.; Teguia, A. Guinea-Pig production under traditional management. Trop. Anim. Health Prod. 1998, 30, 115-122. [CrossRef] [PubMed]

44. Zahedi, A.; Durmic, Z.; Austen, J.; Lawson, M.; Callahan, L.; Jarhine, J.; Ryan, V. Cryptosporidium homai n. sp. (Apicomplexa, Cryptosporidiiae) from Guinea pigs (Cavia porcellus). Vet. Parasitol. 2017, 245, 92-101. [CrossRef] [PubMed]

45. Veronesi, F.; Fioretti, D.P.; Morganti, G.; Bietta, A.; Moretta, I.; Moretta, A.; Traversa, D. Occurrence of Giardia duodenalis infection in chinchillas (Chinchilla lanigera) from Italian breeding facilities. Res. Vet. Sci. 2012, 93, 807-810. [CrossRef] [PubMed]

46. Qi, M.; Yu, F.; Li, S.; Wang, H.; Luo, N.; Huang, J.; Zhang, L. Multilocus genotyping of potentially zoonotic Giardia duodenalis in pet chinchillas (Chinchilla langiera) in China. Vet. Parasitol. 2015, 208, 113-117. [CrossRef] [PubMed]

47. Fialho, C.G.; Oliveira, R.G.; Teixeira, M.C.; Marques, S.M.T.; Oliviera, R.G.; Araujo, A.P. Comparison of protozoan infection between chinchillas (Chinchillas lanigera) from a commercial breeding facility in southern Brazil and chinchillas from a natural reserve in Chile. Parasitol. Latinoam. 2008, 63, 85-87.

48. Gurgel, A.C.F.; Santori, A.D.S.; de Araujo, F.A.P. Protozoan parasites in captive chinchillas (Chinchilla lanigera) reaised in the State of Rio Grande do Sul, Brazil. Parasitlol. Latinoam. 2005, 60, 186-188.

49. Levecke, B.; Meulemans, L.; Dalemans, T.; Casaert, S.; Claerebout, E.; Geurden, T. Mixed Giardia duodenalis assemblage A, B, C and E infection in pet chinchillas (Chinchilla lanigera) in Flanders (Belgium). Vet. Parasitol. 2011, 177, 166-170. [CrossRef] [PubMed]

50. Soares, R.M.; de Souza, S.L.P.; Silviera, L.H.; Funada, M.R.; Richtzenhain, L.J.; Gennari, S.M. Genotyping of potentially zoonotic Giardia duodenalis from exotic and wild animals kept in captivity in Brazil. Vet. Parasitol. 2011, 180, 344-348. [CrossRef] [PubMed]

51. Martino, P.E.; Bautista, E.L.; Gimeno, E.J.; Stanchi, N.E.; Radman, N.E. Fourteen-year status report of fatal illnesses in captive chinchillas (Chinchilla lanigera). J. Appl. Anim. Res. 2017, 45, 310-314. [CrossRef]

52. Lucena, R.B.; Giaretta, P.R.; Tessele, B.; Fighera, R.A.; Kommers, G.D.; Irigoyen, L.F.; Barros, S.L. Diseases of Chinchillas (Chinchilla lanigera). Prequisa Vet. Bras. 2012, 32, 529-535. [CrossRef]

53. Williams, O.L. Cestodes from the Eastern Wild Turkeys. J. Parasitol. 1931, 18, 14-20. [CrossRef]

54. Kozicky, E.L. Some Protozoan Parasites of the Eastern Wild Turkeys in Pennsylvania. J. Wildl. Manag. 1948, 12, 263-266.

55. Hon, L.T.; Forrester, D.J.; Williams, L.E., Jr. Helminths of Wild Turkeys in Florida. Proc. Helminthol. Soc. Wash. 1975, 42, 119-127.

56. Maxfield, B.G.; Reid, W.M.; Hayes, F.A. Gastrointestinal Helminths from Turkeys in Southeastern Unites States. J. Wildl. Manag. 1963, 27, 261-271. [CrossRef]

57. Castle, M.C.; Christensen, B.M. Blood and Gastrointestinal parasites of eastern wild turkeys from Kentucky and Tennessee. J. Wildl. Dis. 1984, 20, 190-196. [CrossRef] [PubMed]

58. Ruff, M.D.; Schorr, L.; Davidson, W.R.; Nettles, V.F. Prevalence and Identity of Coccidia in Pen-Raised Wild Turkeys. J. Wildl. Dis. 1988, 24, 711-714. [CrossRef] [PubMed] 
59. Hopkins, B.A.; Skeeles, J.K.; Houghten, G.E.; Slagle, D.; Gardner, K. A survey of infectious diseases in the wild turkeys (Meleagridis gallopavo silvestris) in Arkansas. J. Wildl. Dis. 1990, 26, 468-472. [CrossRef] [PubMed]

60. Mc Junkin, J.W.; Applegate, R.D.; Zelmer, D.A. Enteric Helminths of Juvenile and Adult Wild Turkeys (Meleagris gallopavo) in Eastern Kansas. Avian Dis. 2003, 47, 1481-1485. [CrossRef] [PubMed]

61. Brener, B.; Tortelly, R.; Muniz-Perriera, P.C.; Pinto, R.M. Cheilospirura hamulosa (Diesing, 1851) (Nematoda, Acuariodea) turkeys in Brazil: Occurrence and pathology. Arquivo Brasiliero de Veterinaria e Zootecnia 2006, 58, 287-290. [CrossRef]

62. Brener, B.; Tortelly, R.; Menezes, C.M.; Muniz-Perriera, L.C.; Pinto, R.M. Prevalence and pathology of the nematode Heterakis gallinarum, the trematode Paratanasia bragai, and protozoan Histomanas meleagridis in the turkey, Meleagris gallopavo. Memorias do Instituto Oswaldo Cruz 2006, 101, 677-681. [CrossRef] [PubMed]

63. Pinto, R.M.; Brener, B.; Tortelly, R.; Menezes, R.C.; Muniz-Perriera, L.C. Capillariid nematodes in Brazillian turkeys, Meleagris gallopavo (Galliformes, Phasianidae): Pathology induced by Baruscapillaria obsignata and Eucoleus annulatus (Trichinelloidea, Capillariidae). Memorias do Instituto Oswaldo Cruz 2008, 103, 677-681. [CrossRef]

64. Pinto, R.M.; Brener, B.; Menezes, R.C.; Tortelly, R. Two cestodes species in Brazilian turkeys, Meleagris gallopavo (Galliformes, Phasianidae): Pathology induced by Hymenolepsis cantaniana and occurrence of Raillietina tetragona. Parasitol. Latinoam. 2008, 63, 81-84.

65. Oates, D.W.; Wallner-Pendleton, E.A.; Kanev, I.; Sterner, M.C.; Collins, C.E.; Biscof, N.; Boyd, E.D. A survey of infectious diseases and parasites in wild turkeys for Nebraska. Trans. Neb. Acad. Sci. 2005, 30, $25-31$.

66. Godwin, M.A.; Steffens, W.L.; Russell, I.D.; Brown, J. Diarrhoea Associated with Intestinal Cryptosporidiosis in Turkeys. Avian Dis. 1988, 32, 63-67. [CrossRef]

67. Woodmansee, D.B.; Pavlasek, I.; Pohlenz, F.L.; Moon, H.W. Subclinical Cryptosporidiosis of Turkeys in Iowa. J. Parasitol. 1988, 74, 898-900. [CrossRef] [PubMed]

68. Hill, G.E.; Doucet, S.M.; Ruchholz, R. The effect of coccidian infection on iridescent plumage coloration in wild turkeys. Anim. Behav. 2005, 69, 387-394. [CrossRef]

69. George, R.; Bolen, E. Endoparasites of Black-Bellied Whistling Ducks in Southern Texas. J. Wildl. Dis. 1975, 11, 17-25. [CrossRef] [PubMed]

70. Abou Laila, M.; El-Bahy, N.; Hilali, M.; Yokoyama, N.; Igarashi, I. Prevalence of the enteric parasites of ducks from Behera governorate, Egypt. J. Protozool. Res. 2011, 21, 36-44.

71. Muhairwa, A.P.; Msoffe, P.L.; Ramadhani, S.; Mollel, E.L.; Mtambo, M.M.A.; Kassuku, A.A. Prevalence of gastro-intestinal helminths in free-ranging ducks in Morogoro Municipality, Tanzania. Livest. Res. Rural Dev. 2007, 19, 4.

72. Waruiru, R.M.; Mavuti, S.K.; Mbuthia, P.G.; Njagi, L.W. Survey and intensity of gastrointestinal helminth infestation of free ranging domestic ducks in Kenya. Livest. Res. Rural Dev. 2018, 30, 4.

73. Paul, T.; Lawal, J.R.; Ejeh, E.F.; Ndhadi, J.J.; Peter, I.D.; Bello, A.M.; Wakil, Y. Survey of helminth parasites of free range Muscovy ducks (Anas platyrynchos) slaughtered in Gombe, North Eastern Nigeria. Int. J. Poult. Sci. 2015, 14, 466-470. [CrossRef]

74. Adejinmi, J.O.; Oke, M. Gastro-intestinal Parasites of Domestic Ducks (Anas platyrhynchos) in Ibadan Southwestern Nigeria. Asian J. Poult. Sci. 2011, 5, 46-50. [CrossRef]

75. Farias, J.D.; Canaris, A.G. Gastrointestinal helminths of the Mexican duck Anas platyrhynchos diazi Ridgeway, from North Central Mexico and Southwestern United States. J. Wildl. Dis. 1986, 22, 51-54. [CrossRef] [PubMed]

76. Mercado-Reyes, M.; Angulo-Castillo, S.; Clemente- Sanchez, F.; Hernandez-Llamas, A.; Gonzalez-Rojas, J.I.; Lopez-Torez, E.; Tavizon-Garcia, P. Presence of helminths in the Mexican Duck (Anas platyrhynchos diazi) of the Zacatecano Plateau, Mexico. Agrocencia 2010, 44, 931-939.

77. Sokol, R.; Ras- Norynska, M.; Gesek, M.; Murawska, D.; Hanzal, V.; Janiszewski, P. The parasites of mallard ducks (Anas platyrhynchos) as an indicator of health status and quality of the environment. Ann. Parasitol. 2016, 62, 351-353. [PubMed]

78. Hoque, M.A.; Hassan, M.M.; Haque, E.; Shaikat, A.H.; Khan, S.A.; Alim, A.; Skerratt, L.F.; Islam, A.; Tun, H.M.; Dissanayake, R.; et al. A survey of gastro-intestinal parasitic infection in domestic and wild birds in Chittagong and Great Sylhet, Bangladesh. Prev. Vet. Med. 2014, 117, 305-312. [CrossRef] [PubMed] 
79. Yoshino, T.; Uemura, J.; Endoh, D.; Kaneko, M.; Osa, Y.; Asakawa, M. Parasitic nematode of anseriform birds in Hokkaido, Japan. Helminthologia 2009, 46, 117-122. [CrossRef]

80. Grower, W.C. Abundance of Some Parasites of Wild Ducks. J. Wildl. Manag. 1938, 2, 223-232. [CrossRef]

81. Callait-Cardinal, M.P.; Chauve, C.; Reynaud, C.; Alogninouwa, T.; Zenner, L. Infectivity of Histomonas meleagridis in ducks. Avian Pathol. 2006, 35, 109-116. [CrossRef] [PubMed]

82. Bano, L.; Natale, A.; Vascellari, M.; Comin, D.; Mutinelli, F.; Agnoletti, F. First Report of Parasitic Esophagitis by Streptocara incognita in Muscovy Ducks (Cairina moschata domesticus) in Italy. Avian Dis. 2005, 49, $298-300$. [CrossRef] [PubMed]

83. Richter, D.; Weigand-Tripp, G.; Burkhardt, E.; Kaleta, E.F. Natural infections by Cryptosporidium spp. in farm-raised ducks and geese. Avian Pathol. 1994, 23, 277-286. [CrossRef] [PubMed]

84. Kimura, G.G. Cochmosoma rostratum spp. nov., an intestinal flagellate of Domesticated ducks. Trans. Am. Microsc. Soc. 1934, 53, 102-115. [CrossRef]

85. Bollinger, T.K.; Barker, I.K.; Agnes Fernando, M. Effects of Intestinal flagellate, Cochlosoma anatis, on Intestinal Mucosal Morphology and Disaccharidase Activity in Muscovy Ducklings. Int. J. Parasitol. 1996, 26, 533-542. [CrossRef]

86. Barker, T.K.; Barker, I.K. Runting of Ducklings Associated with Cochlosoma anatis infection. Avian Dis. 1996, 40, 181-185.

(C) 2019 by the authors. Licensee MDPI, Basel, Switzerland. This article is an open access article distributed under the terms and conditions of the Creative Commons Attribution (CC BY) license (http:/ / creativecommons.org/licenses/by/4.0/). 